\title{
Persepsi Konsumen terhadap Daging Kerbau dan Daging Sapi di Kecamatan Candipuro Kabupaten Lumajang
}

\author{
Perception of Consumer's Buffalo Meat and Beef in Subdistrict Candipuro, District of Lumajang \\ A. M. Permata ${ }^{1)}$, Komariah' ${ }^{2)}$, L. Cyrilla ${ }^{2)}$ \\ 1) Program Studi Teknologi Produksi Ternak \\ ${ }^{2}$ Departemen Ilmu Produksi dan Teknologi Peternakan Fakultas Peternakan IPB \\ Jl Agatis Kampus IPB Dramaga Bogor \\ Email koresponden author: luciwanto@gmail.com
}

\begin{abstract}
Consumer of buffalo meat in Indonesia are low because of it's negative image. Consumer has perception that buffalo meat has tough and hard texture, dark color, and strong smell which makes it less favored. This research aims to identify the consumer's characteristic and perceptions on buffalo meat and beef also to analyze the relationship of perceptions and consumer's characteristic. This research used 50 respondents with purposive sampling technique. The research method used are descriptive analysis to describe characteristic and perception of consumer and correlational test Rank Spearman to know relation between consumer characteristic and perception with buffalo meat. The result showed that consumer's perception in Candipuro Subdistrict prefered beef $(64 \%)$ than buffalo meat $(36 \%)$. The average score of perception shows that consumers have good perception on buffalo meat with a score of 2.28. Aspects of product quality is the aspect with the lowest score of 2.00 and the aspect with the highest score is the religion aspect with a score of 3.00. The result correlational test Rank Spearman showed that occupation and in direction with consumer perseption rate of buffalo meat.
\end{abstract}

Keywords : beef, buffalo meat, perception

\section{PENDAHULUAN}

Daging merupakan sumber protein asal hewan yang bermutu tinggi karena memiliki komponen bahan pangan yang dibutuhkan oleh tubuh. Selain itu, kandungan asam amino esensial lengkap dan seimbang serta lebih mudah dicerna tubuh dibanding protein nabati. Salah satu ternak alternatif yang berpotensi untuk memenuhi kebutuhan daging dalam negeri yaitu kerbau. Menurut Naveena dan Kiran (2014), komposisi, kualitas, karakteristik organoleptik dan keunggulan tambahan seperti rendah lemak dan kolesterol dari daging kerbau hampir sama dengan daging sapi. Ternak yang dipotong umumnya berasal dari ternak yang tua (8-10 tahun) dan digunakan sebagai ternak kerja sehingga kualitas daging rendah. Dibandingkan dengan daging sapi, daging kerbau memiliki tekstur lebih kasar dan liat, warna daging lebih gelap, dan aroma kurang tajam apabila dipotong pada umur yang sama. Hal ini merupakan bentuk persepsi masyarakat yang menjadi salah satu faktor yang dapat mempengaruhi tingkat konsumsi daging kerbau.

Kerbau merupakan ternak ruminansia besar yang dapat bertahan hidup dengan pakan terbatas baik dari segi kualitas maupun kuantitas. Kerbau toleran terhadap penyakit atau parasit di daerah tropis dan lembab serta tersebar luas di berbagai wilayah. Hal ini mengindikasikan bahwa kerbau dapat beradaptasi dengan baik pada berbagai wilayah agroekosistem di Indonesia (Anggraeni dan Triwulanningsih 2007). Kabupaten Lumajang merupakan salah satu kabupaten yang memiliki banyak populasi kerbau di Jawa Timur. Beberapa wilayah Kabupaten Lumajang seperti Kecamatan Candipuro, masyarakatnya pernah mengonsumsi daging kerbau. Berdasarkan BPS (2017), populasi ternak kerbau di Kabupaten Lumajang sebanyak 4 747 ekor pada tahun 2015 dan 4797 ekor pada tahun 2016, serta produksi daging kerbau sebanyak $38002 \mathrm{~kg}$ di tahun 2015 dan $39585 \mathrm{~kg}$ di tahun 2016.

Persepsi merupakan sudut pandang seseorang terhadap suatu hal. Menurut Setiadi(2010), persepsi memiliki sifat subjektif, karena setiap orang akan memandang suatu objek atau situasi dengan cara yang berbeda-beda. Timbulnya persepsi berbeda-beda yang dibentuk oleh masyarakat dapat mempengaruhi sikap konsumen untuk mengambil keputusan dalam mengonsumsi daging kerbau. Perlu pengkajian dan penelitian guna mengetahui persepsi konsumen terhadap daging kerbau. Selain itu, diperlukan identifikasi faktor-faktor persepsi yang berpengaruh terhadap konsumen daging kerbau sehingga dapat mengetahui daya terima konsumen terhadap daging kerbau. Tujuan penelitian adalah mengidentifikasi karakteristik dan persepsi konsumen terhadap daging kerbau dan daging sapi 
serta menganalisis hubungan karakteristik konsumen dan persepsi terhadap daging kerbau.

\section{MATERI DAN METODE}

\section{Waktu dan Lokasi Penelitian}

Penelitian ini akan dilaksanakan pada bulan Mei hingga Juli 2018. Penelitian ini dilaksanakan di Kecamatan Candipuro, Kabupaten Lumajang.

\section{Alat}

Alat yang digunakan pada penelitian ini adalah kuesioner yang terdiri dari pertanyaan tertutup dan terbuka. Kuesioner penelitian berisi karakteristik reponden dan persepsi responden tehadap daging kerbau dan daging sapi. Alat lain yang digunakan adalah alat tulis, kamera untuk dokumentasi, dan laptop dengan perangkat lunak untuk pengolahan data.

\section{Penentuan Responden}

\section{Prosedur}

Jumlah responden yang digunakan pada penelitian ini adalah 50 responden. Jumlah tersebut merupakan ukuran yang diterima dan memenuhi syarat dari suatu metode penelitian. Silalahi (2012), menyatakan bahwa minimum responden yang digunakan untuk penelitian adalah 30 responden.

Responden dipilih dengan cara nonprobability sampling menggunakan teknik purposive sampling. Responden yang dipilih adalah konsumen individu yang berusia 17 tahun atau lebih dan pernah mengonsumsi daging kerbau dan daging sapi. Selain itu, juga didasarkan pada kesediaan responden untuk diwawancarai.

\section{Pengumpulan Data}

Data yang digunakan dalam penelitian ini adalah data primer dan data sekunder. Pengumpulan data primer dilakukan melalui wawancara langsung dengan responden. Pengumpulan data sekunder dapat diperoleh melalui literatur, yaitu buku-buku, jurnal, skripsi, tesis, profil desa, informasi tertulis dan data-data lainnya yang mendukung kebutuhan data mengenai fokus penelitian.

Data yang dikumpulkan pada penelitian ini terdiri dari karakteristik responden (jenis kelamin, usia, tingkat pendidikan, pekerjaan, penghasilan per bulan, dan jumlah tanggungan keluarga), serta persepsi. Persepsi didasarkan pada literatur dari Kotler (2000), meliputi aspek budaya, agama, sosial, dan kualitas produk.

\section{Penentuan Skor Persepsi}

Pengukuran persepsi responden menggunakan skala Likert dengan 3 skala yang dikategorikan menjadi TS=Tidak Setuju, $\mathrm{S}=$ Setuju, dan $\mathrm{SS}=$ Sangat Setuju. Skala yang digunakan pada penelitian ini, yaitu pada rentang nilai 1-3. Nilai 1 untuk pertanyaan tidak setuju, nilai 2 untuk pertanyaan setuju, dan nilai 3 untuk pertanyaan sangat setuju. Setelah didapatkan data dari setiap pernyataan, maka menghitung skor akhir dari setiap pernyataan. Skor persepsi akhir dihitung dengan cara meratakan skor setiap aspek persepsi yaitu aspek budaya, agama, sosial, dan kualitas produk. Nilai rentang skala dalam menentukan tingkatan persepsi menggunakan rumus menurut Agustin (2011).

Berdasarkan perhitungan rentang skala tersebut, diperoleh hasil seperti pada Tabel 1.

Tabel 1. Skala tingkat persepsi responden

\begin{tabular}{ll}
\hline Nilai & Tingkat Persepsi \\
\hline $1,00-1,66$ & Buruk \\
$1,67-2,33$ & Baik \\
$2,34-3,00$ & Sangat Baik \\
\hline
\end{tabular}

\section{Analisis Data}

Analisis data digunakan untuk menjawab masalah dan tujuan penelitian yang telah dirumuskan dengan menggunakan pendekatan kualitatif. Analisis data yang digunakan berupa analisis deskriptif guna mendeskripsikan karakteristik dan persepsi responden. Data selanjutnya disajikan dalam bentuk frekuensi, presentase, rataan, dan rataan skor. Hubungan antara karakteristik konsumen dan persepsi dianalisis dengan menggunakan uji Rank Spearman (Silalahi 2012).

\section{Uji Validitas dan Uji Reliabilitas}

Uji validitas digunakan untuk menunjukkan sejauh mana alat pengukur yang digunakan sesuai dengan hal yang ingin diukur. Uji reliabilitas digunakan untuk menunjukkan sejauh mana alat pengukur yang digunakan dapat dipercaya atau diandalkan untuk mengukur gejala yang sama dan hasil pengukuran relatif konsisten.

Kuesioner penelitian yang digunakan reliable karena nilai Cronbach's Alpha lebih dari 0,6 (Silalahi 2012). Tujuan dari uji ini untuk mendukung pernyataan bahwa kuesioner yang digunakan adalah valid dan reliable sehingga menghindari kesalahan dalam penafsiran dari responden terhadap pertanyaan kuesioner.

\section{Uji Korelasi Rank Spearman}

Data penelitian mengenai hubungan antara variabel dianalisis dengan menggunakan uji korelasi Rank Spearman. Koefisien korelasi Rank Spearman dapat digunakan untuk mengukur korelasi atau kaitan antara 2 variabel yang memiliki skala paling sedikit ordinal (Silalahi 2012).

$$
r_{s}=1-\frac{6 \sum d^{2}}{n\left(n^{2}-1\right)}
$$

\section{Keterangan :}

$\begin{array}{ll}r_{s} & : \text { nilai koefisien korelasi Spearman } \\ \mathrm{d} & : \text { selisih antara kedua perangkat peubah } \\ \mathrm{n} & : \text { banyaknya pengamatan }\end{array}$

$$
\text { Rentang skala }=\frac{\text { nilai skala tertinggi-nilai skala terendah }}{\text { banyaknya skala }}=\frac{3-1}{3}=0,66
$$

Gambar 1. Rumus Nilai rentang skala dalam menentukan tingkatan persepsi menggunakan rumus menurut Agustin (2011). 
Data yang telah didapat dari penelitian kemudian ditabulasi dan dianalisis sehingga hasil data diinterpretasikan menjadi 3 tahap, yaitu mengetahui signifikansi hubungan, kekuatan hubungan, dan arah hubungan (Silalahi 2012). Apabila nilai signifikansi $<0,05$ maka berkorelasi (ada hubungan yang berarti), sedangkan nilai signifikansi $>0,05$ maka tidak berkorelasi (tidak ada hubungan yang berarti). Kekuatan hubungan merupakan indikasi rentang keeratan hubungan antar variabel yang terdiri dari 5, yaitu rentang antara $0,00-0,25=$ korelasi sangat lemah; 0,26-0,50= korelasi cukup; 0,51-0,75 = korelasi kuat; 0,76-0,99= korelasi sangat kuat; $1.00=$ korelasi sempurna. Kriteria arah hubungan ada 2, yaitu bernilai positif dan negatif. Nilai koefisien korelasi bernilai positif maka hubungan kedua variabel searah, nilai koefisien korelasi bernilai negatif maka hubungan kedua variabel tidak searah.

\section{HASIL DAN PEMBAHASAN}

\section{Kondisi Umum Kecamatan Candipuro Kabupaten Lumajang}

Kecamatan Candipuro merupakan salah satu Kecamatan yang ada di Kabupaten Lumajang. Luas Kecamatan Candipuro adalah 144,93 $\mathrm{km}^{2}$ dengan jumlah penduduk 69918. Kepadatan penduduknya mencapai 482 jiwa km² yang terdiri dari 34528 laki-laki dan 34999 perempuan. Data penduduk menurut jenjang pendidikan yang ditamatkan terdiri dari 13615 penduduk yang tidak atau belum tamat SD, 19106 penduduk yang tamat SD, 8401 penduduk tamat SLTP, 4291 penduduk yang tamat SLTA, 33 penduduk yang tamat Akademi, 101 penduduk yang tamat Perguruan Tinggi, dan 2764 penduduk yang buta huruf. Wilayah ini terdiri dari 10 desa, 410 RT, 83 RW, dan 61 dusun. Secara geografis Kecamatan Candipuro berbatasan dengan Kecamatan Pasrujambe di sebelah Utara, Kecamatan Pasirian di sebelah Timur, Kecamatan Tempursari di sebelah Selatan, dan Kecamatan Pronojiwo di sebelah Barat dengan ketinggian wilayah $322 \mathrm{~m}$ dpl dan curah hujan $2018 \mathrm{~mm}_{\text {tahun }}{ }^{-1}$.

Responden di Kecamatan Candipuro setidaknya pernah mengonsumsi daging sapi dan kerbau. Daging sapi dapat diperoleh dengan cara membeli di pasar tradisional. Berbeda dengan daging sapi, daging kerbau di Kecamatan Candipuro tidak dijual di pasaran. Hal ini karena memang daging kerbau masih belum umum dijual secara komersial. Responden memperoleh daging kerbau dengan cara memotong atau menyembelih sendiri. Biasanya responden menyediakan daging kerbau untuk kegiatan atau acaraacara tertentu, seperti pernikahan atau hajatan lainnya.

\section{Karakteristik Umum Responden}

Karakteristik umum responden yang digunakan dalam penelitian ini meliputi jenis kelamin, usia, tingkat pendidikan, pekerjaan, penghasilan per bulan, dan jumlah tanggungan keluarga. Berdasarkan hasil kuesioner yang ada, maka diperoleh data karakteristik responden yang dapat dilihat pada Tabel 2.

\section{Jenis Kelamin}

Perbedaan jenis kelamin akan mempengaruhi konsumen dalam menentukan suatu produk yang akan dikonsumsinya. Menurut Sumarwan (2014), jenis kelamin dapat mempengaruhi pengambilan keputusan barang dan jasa.

Jenis kelamin responden didominasi oleh laki-laki sebanyak $80 \%$, sedangkan perempuan sebanyak $20 \%$. Hal ini karena laki-laki sebagai kepala rumah tangga lebih memperhatikan kebutuhan anggota keluarganya dan bertanggung jawab dalam mengatur konsumsi rumah tangga, sehingga dapat dikatakan bahwa peran laki-laki dalam pengambilan keputusan rumah tangga sangat besar. Usia

Usia merupakan salah satu faktor yang mempengaruhi persepsi konsumen dalam proses keputusan untuk menerima sesuatu yang baru, baik produk maupun jasa. Menurut Sumarwan (2014), konsumen adalah semua penduduk pada semua usia. Perbedaan usia akan mengakibatkan perbedaan selera dan kesukaan terhadap produk. Seseorang yang berusia relatif muda akan lebih cepat menerima sesuatu yang baru.

Responden dangan usia 51-70 tahun memiliki frekuensi tertinggi (46\%) dan usia 17-23 tahun memiliki frekuensi terendah (2\%). Hal ini karena responden yang

Tabel 2. Karakteristik umum responden

\begin{tabular}{|c|c|c|c|}
\hline Aspek & Variabel & $\begin{array}{l}\text { Jumlah } \\
\text { responden }\end{array}$ & $\begin{array}{c}\text { Persentase } \\
(\%)\end{array}$ \\
\hline \multirow{2}{*}{$\begin{array}{l}\text { Jenis } \\
\text { Kelamin }\end{array}$} & Laki-laki & 40 & 80 \\
\hline & Perempuan & 10 & 20 \\
\hline Total & & 50 & 100 \\
\hline \multirow[t]{5}{*}{ Usia (tahun) } & $17-23$ & 1 & 2 \\
\hline & $24-30$ & 1 & 2 \\
\hline & $31-40$ & 9 & 18 \\
\hline & $41-50$ & 16 & 32 \\
\hline & $51-70$ & 23 & 46 \\
\hline Total & & 50 & 100 \\
\hline \multirow[t]{3}{*}{ Pendidikan } & Tidak/Tamat SD & 14 & \\
\hline & SMP/SMA & 35 & 70 \\
\hline & Diploma/Sarjana & 1 & 2 \\
\hline Total & & 50 & 100 \\
\hline \multirow[t]{4}{*}{ Pekerjaan } & Petani/Peternak & 4 & 8 \\
\hline & IRT & 9 & 18 \\
\hline & Buruh & 11 & 22 \\
\hline & Pegawai swasta & 26 & 52 \\
\hline Total & & 50 & 100 \\
\hline Pendapatan & $1500-2500$ & 20 & 40 \\
\hline \multirow[t]{2}{*}{ (000 Rp) } & $>2500-3500$ & 23 & 46 \\
\hline & $>3500-5000$ & 7 & 14 \\
\hline Total & & 50 & 100 \\
\hline $\begin{array}{l}\text { Jumlah } \\
\text { Anggota }\end{array}$ & $2-4$ orang & 40 & 80 \\
\hline Keluarga & $>$ 4orang & 10 & 20 \\
\hline Total & & 50 & 100 \\
\hline
\end{tabular}


mendominasi adalah usia antara 51-70 tahun lebih banyak memiliki pengalaman dari lingkungan tempat tinggal, serta pengetahuan dan informasi untuk menerima sesuatu yang baru. Selain itu, kelompok usia tersebut merupakan kelompok yang cenderung berpikir rasional, karena konsumen sudah memiliki pertimbangan tertentu dalam mengambil keputusan dan mengerti tentang produk yang akan dipilih sesuai dengan seleranya.

\section{Pendidikan}

Tingkat pendidikan seseorang mempengaruhi cara berpikir, sudut pandang, persepsi terhadap suatu masalah. Menurut Sumarwan (2014), seseorang memiliki pendidikan yang lebih baik akan sangat responsif terhadap informasi. Seseorang yang memiliki pengetahuan dan pendidikan yang lebih baik cenderung untuk memilih mengonsumsi makanan yang lebih baik kualitasnya dibandingkan seseorang yang berpendidikan rendah.

Tabel 2 menunjukkan bahwa tingkat pendidikan SMP/SMA memiliki frekuensi tertinggi (70\%), sedangkan tingkat pendidikan Diploma/Sarjana memiliki frekuensi terendah (2\%). Hal ini menunjukkan bahwa responden sebagian besar menamatkan pendidikan pada tingkat pendidikan SMP/SMA sehingga besar kemungkinan juga memiliki pengetahuan yang cukup tentang manfaat dan jenis suatu produk. Menurut Puspitawati (2004), seseorang yang memiliki pengalaman akan memberikan persepsi yang lebih tinggi dibandingkan dengan lainnya karena seseorang yang berpengalaman akan semakin memiliki kemampuan dan keterampilan serta akan lebih pandai dalam memilih sesuatu.

\section{Pekerjaan}

Tingkat pendidikan seseorang akan mempengaruhi jenis pekerjaan seseorang. Hal ini karena tingkat pendidikan akan menjadi salah satu ukuran pertimbangan untuk memperoleh pekerjaan. Jenis pekerjaan tersebut akan mempengaruhi tingkat penghasilan seseorang, kemudian akan mempengaruhi pola konsumsi dan proses keputusan seseorang. Menurut Aisyah (2011), semakin tinggi penghasilan maka proporsi pengeluaran untuk memenuhi kebutuhan semakin meningkat.

Tabel 2 menunjukkan bahwa sebanyak 52\% responden memiliki pekerjaan pegawai swasta, 22\% responden sebagai buruh, 18\% sebagai ibu rumah tangga, dan 4\% sebagai petani/peternak. Responden yang memiliki pekerjaan pegawai swasta sebagian besar memiliki tingkat pendidikan SMP/SMA. Semua pekerjaan dari responden tersebut berpengaruh terhadap pola konsumsi untuk memenuhi kebutuhan keluarga.

\section{Penghasilan}

Keputusan konsumen berhubungan dengan produk yang dipengaruhi oleh jumlah penghasilan yang dimiliki sekarang atau yang akan datang. Suhardjo (2008), berpendapat bahwa umumnya jika tingkat penghasilan seseorang naik, maka jumlah dan jenis makanan akan cenderung membaik. Penghasilan rumah tangga sangat besar pengaruhnya terhadap tingkat konsumsi.

Rata-rata penghasilan rumah tangga per bulan berkisar Rp 1.000.000 sampai dengan Rp 5.000.000. Tabel 2 menunjukkan bahwa rata-rata pekerjaan sebagai pegawai swasta memiliki penghasilan per bulan yaitu Rp 2.500 .000 - Rp 3.500.000 sebanyak 46\%.

\section{Jumlah Tanggungan Keluarga}

Jumlah tanggungan keluarga responden cukup beragam yaitu berkisar 1-6 orang. Anggota keluarga yang menjadi tanggungan ialah istri atau suami serta anak-anak baik yang sudah berumur produktif maupun non produktif. Sumarwan (2014), menyatakan bahwa jumlah anggota keluarga akan menentukan jumlah dan pola konsumsi suatu barang dan jasa.

Jumlah anggota dalam penelitian ini dibagi menjadi 2 kelompok yaitu kelompok yang memiliki 2-4 orang dan lebih dari 4 orang. Hasil penelitian menunjukkan bahwa masyarakat sebagian besar memiliki jumlah anggota 2-4 orang berjumlah $81,6 \%$, sedangkan responden dengan jumlah anggota lebih dari 4 berjumlah 18,4\%. Rata-rata jumlah anggota rumah tangga di Kecamatan tersebut sebesar 3 jiwa.

\section{Persepsi Konsumen terhadap Daging Kerbau}

Persepsi menentukan keputusan konsumsi yang dilakukan oleh konsumen. Persepsi baik akan mendorong konsumen untuk memperoleh dan mengonsumsi suatu produk. Persepsi setiap individu berbeda-beda, sehingga bersifat subjektif. Rataan skor persepsi responden terhadap daging kerbau dapat dilihat pada Tabel 3.

Pada Tabel 3 terlihat bahwa semua aspek yang diamati tergolong baik. Rataan skor tertinggi berada pada aspek agama, yaitu tidak ada larangan untuk mengonsumsi daging kerbau (halal). Rataan skor terendah juga berada pada aspek kualitas produk, yaitu daging kerbau memiliki warna yang lebih gelap. Aspek agama mendapatkan persepsi sangat baik, karena responden memerhatikan kehalalan produk yang akan dikonsumsi. Menurut profil Kecamatan Candipuro hampir 99\% mayoritas penduduknya beragama Islam. Aspek budaya mendapatkan persepsi yang baik, karena budaya konsumsi responden yang muncul dipengaruhi oleh pengaruh sosial. Selain itu, Indonesia identik dengan acara dan kegiatan kebudayaan. Tradisi peninggalan Hindu mengonsumsi daging kerbau masih ada, sehingga sampai sekarang masih terbawa dan berkembang dalam masyarakat.

Aspek sosial mendapatkan persepsi yang baik, karena responden turut berperan dalam memperkenalkan daging kerbau kepada lingkungannya. Aspek kualitas produk mendapatkan persepsi yang baik, karena adanya pengalaman dan pengetahuan dari lingkungan, sehingga responden menerima dan menjadi terbiasa untuk mengonsumsi daging kerbau. Menurut Setiadi (2010), persepsi konsumen dipengaruhi oleh pikiran dan lingkungan sekitar. Faktor lingkungan dapat berasal dari keluarga dan pertemanan sosial, serta kebudayaan dan agama konsumen. Semua persepsi responden yang terbentuk dengan memproses informasi dari berbagai sumber akan membentuk citra positif, sehingga responden mempunyai pengalaman yang cukup dan akan terus menggunakan produk yang sama secara berulang-ulang.

Persepsi konsumen terhadap daging kerbau dapat ditinjau dari berbagai aspek, seperti budaya, agama, sosial, dan kualitas produk. Budaya merupakan salah satu aspek 
Tabel 3. Rataan skor persepsi responden terhadap daging kerbau

\begin{tabular}{|c|c|c|c|}
\hline Aspek & Sub Aspek & Variabel & Rataan Skor \\
\hline Agama & Agama & Tidak ada larangan untuk mengonsumsi daging kerbau (halal) & 3,00 \\
\hline Kualitas produk & Organoleptik & Daging kerbau memiliki aroma yang kurang tajam & 2,36 \\
\hline Kualitas produk & Organoleptik & Daging kerbau memiliki rasa yang enak & 2,26 \\
\hline Adat Budaya & Budaya & $\begin{array}{l}\text { Menyediakan daging kerbau sebagai menu pada acara tertentu (pernikahan/ } \\
\text { khitanan/ hajatan lainnya) }\end{array}$ & 2,24 \\
\hline Sosial & Keluarga & Ada pengaruh keluarga bagi konsumen dalam mengonsumsi daging kerbau & 2,24 \\
\hline Sosial & Pertemanan & $\begin{array}{l}\text { Ada pengaruh teman atau kelompok sosial bagi konsumen dalam mengon- } \\
\text { sumsi daging kerbau }\end{array}$ & 2,24 \\
\hline Adat Budaya & Budaya & Menyediakan daging kerbau olahan sebagai kelengkapan hidangan lebaran & 2,16 \\
\hline Kualitas produk & Organoleptik & Daging kerbau liat & 2,02 \\
\hline & & $\begin{array}{c}\text { Kualitas produk } \\
\text { Organoleptik } \\
\text { ng kerbau memiliki warna yang lebih gelap }\end{array}$ & 2,00 \\
\hline Rataan skor akhir & & & 2,28 \\
\hline
\end{tabular}

penting yang harus diperhatikan karena budaya tumbuh di dalam suatu masyarakat. Antar suatu kelompok masyarakat memiliki budaya yang berbeda-beda. Daerah Lumajang memiliki beragam budaya karena adanya perpaduan etnis Jawa, Madura, dan Tengger. Salah satunya adalah tradisi menyambut 1 suro, yaitu sebuah ritual digelar setiap tahun untuk mengungkapkan rasa syukur kepada Tuhan dan mengenang Maheso Suro yang dipercaya telah memberi kemakmuran masyarakat. Tradisi tersebut sudah dilakukan sejak lama dan sudah menjadi turun temurun. Selain untuk upacara keagamaan, daging kerbau juga dikonsumsi untuk keperluan keluarga, seperti pernikahan atau hajatan lainnya. Adanya tradisi tersebut, masyarakat menjadi terbiasa untuk mengonsumsi daging kerbau. Hal ini tidak menyurutkan responden untuk mengonsumsi daging sapi apabila membutuhkan dalam jumlah yang sedikit.

Berdasarkan adat budaya, diperoleh rataan skor yaitu 2,20, sehingga dapat disimpulkan bahwa responden memiliki persepsi yang baik. Budaya dan sosial terkait erat satu sama lain dan ada timbal balik diantara keduanya. Kebudayaan lahir dan berkembang diantara masyarakat. Kebudayaan tidak berkembang tanpa masyarakat dan masyarakat tidak berkembang tanpa ada kebudayaan yang mendasarinya, sehingga keduanya dapat mempengaruhi pengambilan keputusan konsumsi seseorang. Persepsi konsumen ditinjau dari segi adat perlu dilakukan karena hal ini mempengaruhi nilai-nilai yang ada pada diri seseorang.

Agama memberikan peran penting dalam membangun nilai-nilai yang ada dalam diri seseorang. Agama juga menentukan konsumsi terhadap suatu produk (daging) terutama terkait kehalalannya. Ternak disembelih dengan ketentuan hukum Islam untuk memperoleh daging yang halal yang telah dijelaskan dalam fatwa MUI tentang standar penyembelihan halal. Ternak yang disembelih adalah ternak yang boleh dimakan dan harus dalam keadaan hidup ketika disembelih.

Menurut SNI (1999), Rumah Pemotongan Hewan (RPH) merupakan kompleks bangunan dengan disain dan konstruksi khusus yang memenuhi persyaratan teknis dan higiene tertentu serta digunakan sebagai tempat memotong hewan potong selain unggas bagi konsumsi masyarakat. RPH juga digunakan sebagai sarana pelayanan masyarakat dalam penyediaan daging yang Aman, Sehat, Utuh, dan Halal (ASUH). Selain RPH, juga terdapat Tempat Pemotongan Hewan (TPH) yang biasanya hanya digunakan untuk memotong ternak saja. Berbeda dengan tempat pemotongan sapi yang berada di RPH, pemotongan kerbau berada di TPH dan termasuk dalam golongan TPH tradisional. Pelaksanaan pemotongan atau penyembelihan kerbau dapat dilakukan oleh sembarang orang dan sembarang tempat, tetapi harus memenuhi beberapa persyaratan tertentu, dan menggunakan fasilitas atau peralatan khusus, sehingga karkas atau daging yang dihasilkan layak dan aman dikonsumsi oleh masyarakat. Berdasarkan tipe fasilitas yang digunakan dalam pelaksanaan pemotongan ternak, tempat pemotongan kerbau di Kecamatan Candipuro termasuk ke dalam tempat pemotongan terbuka di pedesaan (Williamson dan Payne 1993). Tempat pemotongan hewan terbuka tersebut sederhana karena terdapat di pedesaan yang belum maju dan fasilitas yang digunakan masih relatif sederhana, yaitu berupa penggantung-penggantung berkerek sederhana yang terbuat dari bahan kayu atau pipa baja dan pelaksanaan pemotongan masih dilakukan oleh jagal-jagal perseorangan di lapangan terbuka, semak-semak atau halaman belakang rumah.

Menurut SNI (1999), tentang persyaratan rumah potong hewan, yaitu lokasi pembangunan RPH tidak bertentangan dengan Rencana Umum Tata Ruang (RUTR), Rencana Detail Tata Ruang (RDTR), dan Rencana Bagian Wilayah Kota (RBWK), serta tidak berada di tengah kota, letak lebih rendah dari pemukiman penduduk, tidak berada dekat industri logam atau kimia, tidak berada di daerah rawan banjir, dan lahan luas. Masyarakat di Kecamatan Candipuro mayoritas beragama Islam sehingga tidak ada larangan untuk mengonsumsi daging kerbau. Responden memiliki persepsi yang baik ditinjau dari aspek agama 
dengan rataan skor 3,00.

Keputusan konsumen seseorang dipengaruhi oleh lingkungan sosialnya, seperti keluarga, kelompok pertemanan, serta peran dan status sosial konsumen. Keluarga merupakan organisasi paling penting dalam masyarakat. Keluarga juga merupakan kelompok kecil yang paling kuat pengaruhnya terhadap persepsi dan perilaku seseorang. Menurut Setiadi (2010), beberapa peran di dalam anggota keluarga terdapat untuk memutuskan konsumsi keluarga, salah satunya adalah peran sebagai pemberi pengaruh (influencer). Pemberi pengaruh ini melaksanakan peran berdasarkan pengalaman yang akan membentuk persepsinya terhadap suatu produk daging, yaitu daging kerbau dan sapi. Selain itu, pemberi pengaruh dapat menjadi orang yang mengajak untuk mengonsumsi daging kerbau dan tentu akan memiliki persepsi baik mengenai daging kerbau. Pemberi pengaruh dalam keluarga untuk mengonsumsi daging kerbau adalah kepala keluarga, sedangkan yang mengambil keputusan dalam keluarga (decision maker) adalah ibu rumah tangga, karena perempuan yang mengatur segala keperluan keluarga. Namun, dalam hal ini decision maker tetap mengikuti influencer yaitu kepala keluarga setelah mendapat keputusan bersama. Selain itu, kelompok pertemanan juga merupakan salah satu bagian dari kehidupan sosial konsumen yang turut dalam membentuk nilai-nilai di dalam diri konsumen. Kelompok pertemanan ini terdapat kelompok referensi, yaitu kelompok yang memperkenalkan perilaku dan gaya hidup baru kepada seseorang, mempengaruhi sikap dan konsep diri seseorang, dan menciptakan tekanan untuk menegaskan yang mungkin akan mempengaruhi pilihan produk dan merek seseorang. Kelompok referensi juga memiliki peran yang sama seperti dengan influencer yaitu orang yang mengajak untuk mengonsumsi daging kerbau dan tentunya memiliki persepsi yang baik terhadap daging kerbau.

Status sosial juga dapat mempengaruhi persepsi konsumen terhadap suatu produk. Status sosial diartikan sebagai posisi seseorang dalam suatu kelompok sosial dalam hubungan yang terjadi di lingkungan masyarakat sekitarnya. Status sosial juga menentukan peran seseorang dalam hidup bermasyarakat. Salah satu cara mendapatkan status sosial adalah dengan melakukan interaksi sosial, karena proses interaksi sosial akan menciptakan hubungan sosial yang terjalin di masyarakat sehingga tercipta status sosial. Status sosial biasanya didapatkan atas dasar latar belakang, seperti garis keturunan atau jabatan yang telah didapatkan sementara. Lebih dari 50\% responden memiliki pekerjaan pegawai swasta, sehingga persepsi responden terhadap daging kerbau lebih baik dibandingkan dengan yang memiliki pekerjaan lainnya. Hal ini karena responden yang memiliki pekerjaan swasta interaksi sosialnya lebih banyak dibanding pekerjaan lainnya. Responden memiliki persepsi yang baik ditinjau dari aspek sosial dengan rataan skor 2,24 .

Kualitas daging merupakan karakteristik daging yang dinilai oleh konsumen. Beberapa faktor kualitas daging yang dimakan meliputi warna, tekstur, keempukan, aroma (bau), dan flavour (cita rasa). Berdasarkan organoleptik yang ditinjau dari aspek kualitas produk, responden memiliki persepsi yang baik terhadap semua variabel yang diamati. Hal ini karena adanya penilaian kepuasan responden yang memilih dan mengonsumsi daging, sehingga mempengaruhi derajat kesukaan terhadap daging kerbau dan sapi. Responden mengonsumsi daging kerbau karena kebiasaan dan sosial budaya masyarakat yang sebelumnya mengonsumsi daging kerbau. Menurut Marques et al. (2016), penilaian kepuasan konsumen terhadap daging tergantung pada respons fisiologis dan sensori individu. Selain itu, penampilan karakteristik visual menjadi syarat intrinsik yang berkorelasi dengan kualitas daging terhadap preferensi konsumen (Banovic et al. 2009).

Menurut responden, daging kerbau memiliki warna yang lebih gelap dibandingkan dengan daging sapi. Berdasarkan rataan skor variabel warna daging kerbau, responden memiliki persepsi yang baik terhadap warna daging kerbau yaitu 2.00. Hal ini sesuai dengan Mendrofa (2017), bahwa daging kerbau memiliki warna yang lebih gelap dibandingkan daging sapi. Warna yang lebih gelap ini karena kandungan jaringan ikat dari daging kerbau lebih banyak dibandingkan dengan daging sapi (Lawrie 2003). Warna yang dapat dilihat mata merupakan kombinasi beberapa faktor yaitu panjang gelombang radiasi cahaya, intensitas cahaya, dan refleksi cahaya. Faktor-faktor yang mempengaruhi warna daging, yaitu umur, jenis kelamin, tingkat aktivitas, dan tipe otot. Faktor-faktor tersebut mempengaruhi penentu utama warna daging, yaitu konsentrasi pigmen daging yang disebut mioglobin (Soeparno 2005).

Menurut responden, daging kerbau termasuk liat. Hal ini sesuai dengan pendapat Mendrofa (2017), bahwa daging kerbau memiliki tingkat keempukan yang liat. Selain itu, tekstur daging kerbau yang lebih kasar menjadi pilihan responden untuk mengonsumsinya karena tidak mudah hancur ketika proses pemasakan yang lama dan tahan lama ketika dilakukan proses pemasakan berulang. Responden menyukai tingkat keempukan daging kerbau dan dapat dilihat dari skor persepsi daging kerbau terhadap tekstur yaitu sebesar 2,02. King et al. (2009), berpendapat bahwa tekstur daging mempengaruhi persepsi konsumen terhadap keempukan daging. Menurut Soeparno (2005), keempukan dan tekstur daging kemungkinan besar merupakan penentu yang paling penting pada kualitas daging. Faktor yang mempengaruhi keempukan daging digolongkan menjadi 2, yaitu faktor antemortem dan postmortem. Faktor antemortem meliputi umur, jenis kelamin, manajemen, dan tingkat stress, sedangkan faktor postmortem yaitu metode pengolahan meliputi metode pemasakan serta penambahan bahan pengempuk.

Daging kerbau memiliki rasa yang enak untuk dikonsumsi. Rahardjo (2016), menyatakan bahwa faktor rasa menjadi pertimbangan utama dari konsumen. Menurut Rahma (2016), rasa enak dapat didefinisikan dari ruang lingkup makanan dan lebih didasarkan pada indera pencecap (lidah) serta hanya berkaitan dengan rasa yang dapat dideteksi oleh mulut. Faktor yang mempengaruhi rasa adalah aroma yang terdeteksi oleh hidung. Menurut Lawrie (2003), aroma dan flavor daging adalah sensasi yang komplek dan saling terkait. Rasa dan aroma mempunyai 
rangsangan selera, sehingga rasa dan aroma sulit dipisahkan. Flavor dan aroma daging dipengaruhi oleh umur ternak, tipe pakan, jenis kelamin, lemak, bangsa, lama waktu dan kondisi penyimpanan setelah pemotongan, suhu serta lama pemasakan. Daging dari ternak yang lebih tua mempunyai aroma yang lebih kuat dibandingkan ternak yang lebih muda. Menurut responden, daging kerbau memiliki aroma yang kurang tajam dibandingkan dengan daging sapi. Mendrofa (2017), menyatakan bahwa daging kerbau memiliki aroma yang tajam. Hal ini karena responden terbiasa dengan aroma dari daging kerbau, terlebih saat daging kerbau dimasak dengan menambahkan bumbu rempah.

\section{Pengambilan Keputusan terhadap Daging Kerbau dan Daging Sapi}

Perilaku konsumen merupakan perilaku yang memperlihatkan konsumen dalam mencari, membeli, menggunakan, mengevaluasi dan menghabiskan produk serta jasa dengan harapan dapat memuaskan kebutuhannya. Sebelum memutuskan untuk mengonsumsi suatu barang atau jasa, tentunya konsumen akan melalui serangkaian tahapan yang menentukan keputusan akhir pembelian suatu barang atau jasa. Menurut Kotler dan Keller (2007), ada beberapa tahap yang akan dilalui oleh responden sehingga menggambarkan rasa kepuasan terhadap daging, yaitu awareness, knowledge, liking, dan preference. Keputusan responden memilih daging kerbau dan daging sapi terjadi ketika adanya peringkatan seluruh produk daging yang dapat dikonsumsi untuk memperoleh preferensi daging sapi maupun kerbau (Frank 2011). Preferensi setiap konsumen akan berbeda-beda, sehingga bersifat subjektif. Perbedaan ini disebabkan beberapa faktor, seperti faktor individu sendiri dan lingkungan sosial (Azizah 2008).

Tahap awareness/kesadaran merupakan tahap konsumen menyadari adanya suatu produk berupa barang ataupun jasa. Tujuan dalam tahap ini yaitu konsumen mengenal dan mengingat produk tersebut dalam pikiran konsumen. Apabila tujuan ini tercapai, maka produk tersebut akan muncul pertama kali dalam pikiran konsumen. Pengenalan bahan pangan salah satunya berupa daging. Selain daging sapi, daging kerbau dapat dijadikan salah satu produk pangan untuk memenuhi kebutuhan responden. Responden pernah mengonsumsi daging kerbau dan sapi dengan intensitas mengonsumsi daging kerbau (76\%) lebih banyak dibandingkan daging sapi (24\%). Kebiasaan mengonsumsi daging kerbau dilakukan secara bulanan, sedangkan daging sapi dilakukan secara harian $(6 \%)$, mingguan (26\%), dan bulanan (68\%). Hal ini karena daging kerbau lebih banyak dikonsumsi untuk acara-acara tertentu, sedangkan daging sapi dikonsumsi hanya dalam jumlah yang sedikit. Adanya daging kerbau ini menjadikan responden untuk mencobanya, sehingga responden akan merespon dengan baik dan hal ini akan terjadi secara berulang. Menurut Setiadi (2010), pengenalan suatu hal akan mengarah ke dalam ingatan responden dan dapat dijadikan pengalaman pribadi serta pengetahuan.

Tahap knowledge/pengetahuan merupakan tahap responden sudah mengenal dan mengerti mengenai produk berupa daging kerbau dan sapi. Wijayanti (2009), menyatakan bahwa pengetahuan responden muncul ketika menggunakan inderanya untuk menggali kejadian yang belum pernah dilihat atau dirasakan sebelumnya. Pengetahuan terhadap daging kerbau dan sapi dapat dipengaruhi dari pengalaman dan sosial budaya. Pengalaman responden dapat terjadi dari peristiwa yang pernah dialami oleh seseorang dalam berinteraksi dengan lingkungannya. Semakin banyak pengalaman responden, maka semakin bertambah pula pengetahuan responden terhadap suatu produk. Kebudayaan dan kebiasaan keluarga dapat mempengaruhi pengetahuan, persepsi, dan sikap responden dalam mengonsumsi daging. Menurut responden, daging kerbau memiliki sedikit lemak dibandingkan dengan daging sapi. Responden juga mengonsumsi daging kerbau karena pengaruh dari lingkungan sosial, yaitu tetangga-tetangga responden yang juga mengonsumsi daging kerbau. Selain itu, proses mengolah daging kerbau yang lama tidak membuat daging menjadi hancur.

Tahap liking/menyukai merupakan tahap responden mulai menyukai produk berupa barang ataupun jasa yang ditawarkan. Responden menyukai produk tersebut dari pengalaman pribadinya serta keadaan geografis seperti lingkungan sosial dan budaya (Sumarwan 2014). Kondisi ini merupakan langkah responden untuk tetap merespon produk secara berulang-ulang sehingga pada akhirnya akan memilih produk tersebut. Responden menyukai daging kerbau karena memiliki sedikit lemak dibandingkan dengan daging sapi. Responden mengetahui bahwa daging kerbau sedikit lemak dari lingkungan sosial, yaitu tetanggatetangga responden yang juga mengonsumsi daging kerbau. Pengetahuan dari lingkungan sosial ini kemudian menjadi pengalaman responden untuk mengonsumsi dan mengolahnya ke bentuk olahan yang diinginkan responden.

Tahap preference/preferensi, yaitu responden mulai lebih memilih produk tersebut dibandingkan dengan lainnya. Responden menyatakan bahwa lebih menyukai daging sapi (64\%) dibandingkan dengan daging kerbau (36\%). Adapun yang menjadi alasan responden lebih menyukai daging sapi karena dapat dibeli secara eceran $(14,55 \%)$, aroma tidak tajam $(15,02 \%)$, warna daging lebih cerah $(12,21 \%)$, serat daging lebih halus $(14,10 \%)$, lebih empuk $(15,02 \%)$, rasa lebih enak/gurih $(14,55 \%)$, dan terbiasa/tradisi mengonsumsi daging sapi (14,55\%). Alasan responden yang menyukai daging kerbau karena mudah didapat (15\%), aroma kurang tajam (22,50\%), warna daging lebih cerah $(6,50 \%)$, serat daging lebih halus $(6,25 \%)$, lebih empuk $(12,50 \%)$, rasa lebih enak/gurih (15\%), dan terbiasa/tradisi mengonsumsi daging kerbau (21,25\%). Hal ini menunjukkan adanya pengaruh lingkungan sosial dan fisik dalam menentukan persepsi konsumen terhadap daging kerbau dan sapi. Menurut Sumarwan (2014), lingkungan sosial merupakan semua interaksi sosial yang terjadi antara konsumen dengan orang di sekelilingnya, sedangkan lingkungan fisik merupakan segala sesuatu yang berbentuk fisik di sekitar konsumen termasuk di dalamnya berbagai produk, yaitu daging. Lingkungan fisik ini yang memungkinkan responden lebih memilih daging sapi, karena kemudahannya mendapatkan daging sapi yang tersedia di sekitar tempat tinggal responden. Selain itu, daging kerbau tidak setiap saat tersedia di pasar karena 
populasi kerbau rendah.

Produk (daging) yang telah dipilih oleh konsumen kemudian akan dikonsumsi lebih lanjut ke bentuk olahan daging, baik daging kerbau maupun daging sapi. Responden yang memilih daging kerbau diolah menjadi bumbu age (45\%), empal (10\%), gulai (2\%), dan rendang $(2 \%)$. Responden yang memilih daging sapi diolah menjadi bumbu age $(42 \%)$, empal $(13 \%)$, rawon $(3 \%)$, gulai $(2 \%)$, rendang $(2 \%)$, dan bakso $(2 \%)$. Jenis olahan daging yang paling banyak dibuat oleh responden adalah bumbu age. Banyaknya responden yang memilih bumbu age menjadi produknya karena adanya faktor sosial dan budaya, yaitu masakan khas daerah setempat karena pada umumnya responden menyediakan olahan tersebut untuk keperluan pribadi atau acara-acara tertentu.

\section{Hubungan Karakteristik Konsumen dan Persepsi terhadap Daging Kerbau}

Terdapat 5 karakteristik konsumen yang diukur hubungannya dengan persepsi daging kerbau. Persepsi dapat dipengaruhi oleh faktor dari individu tersebut, yaitu karakteristik konsumen. Karakteristik konsumen tersebut meliputi jenis kelamin, usia, tingkat pendidikan, pekerjaan, dan penghasilan. Tabel 4 menyajikan hubungan karakteristik konsumen dan persepsi terhadap daging kerbau.

Hasil uji korelasi Rank Spearman menunjukkan bahwa variabel jenis kelamin memiliki hubungan yang lemah dengan persepsi konsumen terhadap daging kerbau. Variabel usia tidak mempengaruhi tingkat persepsi konsumen terhadap daging kerbau, demikian juga dengan variabel tingkat pendidikan. Penghasilan juga memiliki hubungan yang lemah dengan persepsi konsumen terhadap daging kerbau.

Variabel pekerjaan memiliki hubungan yang signifikan dan searah dengan tingkat persepsi konsumen terhadap daging kerbau. Hal ini menunjukkan bahwa persepsi konsumen terkait erat dengan jenis pekerjaan yang dimiliki oleh responden, karena dengan jenis pekerjaan berbeda akan memiliki sudut pandang yang berbeda-beda. Hal ini sejalan dengan hasil penelitian dari Tuty et al. (2017), bahwa terdapat hubungan yang signifikan antara pekerjaan dengan persepsi konsumen. Morissan (2010), menyatakan bahwa konsumen yang mempunyai jenis pekerjaan tertentu umumnya mengonsumsi barang tertentu yang berbeda

Tabel 4. Hubungan karakteristik konsumen dan persepsi terhadap daging kerbau

\begin{tabular}{llll}
\hline $\begin{array}{l}\text { Karakteristik } \\
\text { Konsumen }\end{array}$ & $\begin{array}{l}\text { Koefisien } \\
\text { korelasi }\end{array}$ & $\begin{array}{l}\text { Signifikasi } \\
(\mathrm{P})\end{array}$ & Keterangan \\
\hline $\begin{array}{l}\text { Jenis } \\
\text { kelamin }\end{array}$ & $-0,237$ & 0,097 & $\begin{array}{l}\text { Hubungan tidak searah, } \\
\text { sangat lemah, tidak } \\
\text { signifikan }\end{array}$ \\
Usia & 0,194 & 0,177 & $\begin{array}{l}\text { Hubungan searah, sangat } \\
\text { lemah, tidak signifikan }\end{array}$ \\
$\begin{array}{l}\text { Tingkat } \\
\text { pendidikan }\end{array}$ & 0,11 & 0,447 & $\begin{array}{l}\text { Hubungan searah, sangat } \\
\text { lemah, tidak signifikan }\end{array}$ \\
Pekerjaan & 0,351 & 0,012 & $\begin{array}{l}\text { Hubungan searah, cukup, } \\
\text { signifikan }\end{array}$ \\
Penghasilan & 0,116 & 0,424 & $\begin{array}{l}\text { Hubungan searah, sangat } \\
\text { lemah, tidak signifikan }\end{array}$ \\
\hline
\end{tabular}

dengan jenis pekerjaan lainnya.

\section{KESIMPULAN}

\section{Simpulan}

Persepsi konsumen terhadap daging kerbau ditinjau dari aspek budaya, agama, sosial, dan kualitas produk tergolong baik dengan rataan skor akhir yaitu 2,28. Responden lebih menyukai daging sapi (64\%) dibandingkan dengan daging kerbau (36\%). Variabel pekerjaan memiliki hubungan yang signifikan dan searah dengan tingkat persepsi konsumen terhadap daging kerbau.

\section{Saran}

Perlu adanya penelitian lebih lanjut mengenai kualitas fisik daging kerbau agar bisa dibandingkan dengan persepsi konsumen.

\section{DAFTAR PUSTAKA}

Agustin. 2011. Analisis persepsi konsumen terhadap daging kelinci di kota Bogor [skripsi]. Bogor (ID): Institut Pertanian Bogor.

Aisyah. 2011. Faktor-faktor yang mempengaruhi preferensi konsumen. Jurnal Pendidikan Ekonomi \& Koperasi UPI 6(1): 168-188.

Anggraeni A, Triwulanningsih E. 2007. Keragaman bobot badan dan morfometrik tubuh kerbau Sumbawa terpilih untuk penggemukan. Prosiding Seminar dan Lokakarya Usaha Ternak Kerbau. Bogor (ID): Pusat Penelitian dan Pengembangan Peternakan.

Azizah I. 2008. Analisis pengaruh persepsi dan preferensi konsumen terhadap keputusan pembelian buah lokal [skripsi]. Bogor (ID): Institut Pertanian Bogor.

[BPS] Badan Pusat Statistik. 2008. Produk Domestik Bruto Per Kapita, Produk Domestik Bruto Per Kapita, dan Pendapatan Nasional Per Kapita [Internet]. [2018 Agustus 20]. Tersedia pada: https://www.bps.go.id.

[BPS] Badan Pusat Statistik Kabupaten Lumajang. 2017. Kecamatan Candipuro dalam Angka. Lumajang (ID): BPS Kabupaten Lumajang.

[BPS] Badan Pusat Statistik Propinsi Jawa Timur. 2017. Tabel Dinamis Subjek Peternakan [Internet]. [2018 Oktober 24]. Tersedia pada: https://jatim.bps.go.id.

[BSN] Badan Standardisasi Nasional. SNI 01-61591999. Rumah Potong Hewan. Jakarta (ID): Badan Standardisasi Nasional.

Banovic M, Grunert KG, Barreira MM, Fontes MA. 2009. Beef perception at the point of purchase: A study from Portugal. Food Quality and Preference (20):335-342.

Frank. 2011. Microeconomics and Behavior. Ed. ke-8. Europe (UK): McGraw Hill International.

Firmansyah T. 2015. Analisis persepsi dan preferensi konsumen terhadap jeruk keprok Garut di Kabupaten Garut, Jawa Barat [skripsi]. Bogor (ID): Institut Pertanian Bogor.

King DA, Wheeler TL, Shackelford SD, Koohmaraie M. 2009. Improving the sensory and nutritional quality fresh meet: Fresh Meat Texture and Tenderness. Cambridge (UK): Woodhead Publishing Ltd. 
Kotler P, Keller KL. 2007. Manajemen Pemasaran. Ed. ke12. Jakarta (ID): Pearson Education Inc.

Lawrie. 2003. Ilmu Daging. Jakarta (ID): UI Pr.

Mendrofa A. 2017. Sifat fisik daging dan preferensi konsumen terhadap daging kerbau dan sapi pada umur berbeda [tesis]. Bogor (ID): Institut Pertanian Bogor.

Morissan MA. 2010. Periklanan Komunikasi Pemasaran Terpadu. Jakarta (ID): Kencana.

Naveena BM, Kiran M. 2014. Buffalo meat quality composition and processing characteristic: contribution to the global economy and nutritional security. Journal of Animal Fronties 4(4): 18-24.

Puspitawati. 2004. Analisis kemitraan antara PT Pertani Persero dengan petani penangkar benih padi di Kabupaten Karawang [tesis]. Bogor (ID): Institut Pertanian Bogor.

Rahardjo CR. 2016. Faktor yang menjadi preferensi konsumen dalam membeli produk frozen food. Jurnal Manajemen dan Start-Up Bisnis 1(1).

Rahma NI. 2016. Klasifikasi pola rasa daging sapi dan daging babi berbasis electronic tongue dengan 17 array sensor menggunakan metode principle component analysis (PCA) dan cluster analysis (CA) [skripsi]. Malang (ID): Universitas Islam Negeri Maulana Malik Ibrahim.

Schiffman, Kanuk. 2000. Perilaku Konsumen. Ed. ke-7. New Jersey (US): Prentice Hall Inc.

Setiadi. 2010. Perilaku Konsumen: Perspektif Kontemporer pada Motif, Tujuan, dan Keinginan Konsumen. Jakarta (ID): Kencana Prenada Media Group.

Silalahi U. 2012. Metode Penelitian Sosial. Bandung (ID): PT Refika Aditama.
Soeparno 2005. Ilmu dan Teknologi Daging. Yogyakarta (ID): Gadjah Mada University Pr.

Suhardjo. 2008. Perencanaan Pangan dan Gizi. Jakarta (ID): PT Bumi Aksara.

Sumarwan. 2014. Perilaku Konsumen Teori dan Penerapannya dalam Pemasaran. Ed ke-2. Bogor (ID): Ghalia Indonesia.

Tuty DWS, Widiyanti E, Utami BW. 2017. Korelasi faktor pembentuk persepsi dengan persepsi konsumen terhadap media pemasaran online (www.goodplant. co.id). Journal of Sustainable Agriculture 32(2): 108115 .

Wijayanti. 2009. Hubungan tingkat pengetahuan wanita tentang HIV/AIDS di resosialisasi argorejo kelurahan kali banteng kulon. Prosiding Seminar Nasional Fakultas Ilmu Kesehatan. Surakarta (ID): Universitas Muhammadiyah Surakarta.

Williamson G, Payne WJA. 1993. Pengantar Peternakan di Daerah Tropis. Yogyakarta (ID): Gadjah Mada University Pr.

Windarti T, Ibrahim M. 2017. Pengaruh kualitas produk dan kualitas pelayanan terhadap kepuasan konsumen produk donat madu (studi kasus konsumen CV Donat Madu Cihanjung-Pekanbaru). JOM FISIP 4(2). 